\title{
PROBLEMS OF FORMING THE POBUZKA AMALGAMATED TERRITORIAL COMMUNITY OF THE KIROVOGRAD REGION (UKRAINE)
}

\section{Tetiana Mykhailenko ${ }^{1}$}

DOI: https://doi.org/10.30525/978-9934-588-11-2_20

The decentralization reform is one of the most widescale reforms in Ukraine today which Ukraine has followed on since 2014. According to the legislation, which formed the basis for the formation regional's Long-term plans, communities must unite or form a new network of territorial associations by their own free desire.

The number of created amalgamated territorial communities (ATC) in Ukraine increased to 951 , the number of community residents increased on 8.8 million people and amounts about10.2 million people for the period from 2015 until September 2019. Incoming of local budgets increased by $25.7 \%$ from 68.6 billion UAH up to 267.0 billion UAH in 2018 [1]. Communities occupy $37.9 \%$ of the Ukraine's territory by area.

Kirovograd region is at the lowest positions by the number of created ATC (21) [1] and takes 19th place in the overall ranking of the regions of our country in 2019. Despite the active process of decentralization, the problem of forming ATC in this region is getting importance.

Today a new Pobuzka amalgamated territorial community of the Kirovograd region (Golovanivsky district) is forming. This ATC aims to unite two localities: the urban village of Pobuzke and the village of Kapitanka. The choice of these localities is mainly determined by the geographical factor: remoteness from other settlements of the Golovanivsky district and land surveying on the south with the Mykolayiv region. There are also political and economic factors - to break out from control of the current district's administrative center - the city of Golovanivsk. The community will be among the smallest in the country by its structure.

The population of Pobuzka ATC will be 7062 people $(20 \%$ of the total number of the Golovanivsky district) and the territory will occupy $13.5 \mathrm{~km}^{2}(1.36 \%$ of the total area of the district) after the union of the urban village of Pobuzke and the village of Kapitanka. The future amalgamated community will belong to communities with population from 5 to 10 thousand people. The administrative center of the Pobuzka ATC will be determined by the urban village of Pobuzke in conformity with the methodical guidance for determination the center of the community.

There will be one general council and one chairman per amalgamated community. The latest is elected by the whole amalgamated territorial community. The Council of ATC can form departments (financial, educational, healthcare, judicial, economic development, etc.), administration and other executive institutions for implementation authority $[2$, p. 70$]$. The creation and composition of these structures are determined

${ }^{1}$ Taras Shevchenko National University of Kyiv, Ukraine 
by the availability of financial resources in the regional budget for the maintenance of the relevant staff.

According to the predicted calculations of the Kirovograd Department of the Association of Ukraine's Cities, the incomes of the Pobuzke as part of ATC will increase from 2 million UAH to 24.77 million UAH per year due to personal and fixed income from personal income tax (PIT). Educational and medical subventions will increase on 18.53 million UAH, reverse subsidies provided for the development will increase on 4.55 million UAH. The Kapitanka's budget will also increase from 2 million UAH to approximately 6.99 million UAH after the amalgamation [3]. In general, incomes will increase almost in 12 and 3.5 times respectively.

Such financial independence will create the basis for community to be able to develop absolutely, to allocate funds for its own needs. It will improve the standard of living of the population. An additional effect will be increasing the competitiveness of the Golovanivsky district, magnification its investment attractiveness and decrease the backwardness of the territory. Cause the social and economic development of the region is inseverable from the development of the community.

The Perspective Development Plan was worked out to attain the successful development of the Pobuzhka ATC. This plan will allow to combine analysis of current events, develop the precise steps for socio-economic development and form a general vision of perspectives. This document includes two blocks: economic and social.

The United States Agency for International Development (USAID) Programme «Decentralisation Offering Better Results and Efficiency» (DOBRE) signed a Memorandum on cooperation with the Kirovohrad Region State Administration and the Regional Council on 18 October 2019. Each community - a partner of the DOBRE program independently prepares projects and decides what to allocate funds to [4]. The result of the signing of this memorandum in the future may be close cooperation and assistance to Pobuzka ATC for its development, implementation some items of the The Perspective Development Plan and new projects.

There are certain risks that could arise in process of forming the Pobuzka ATC: 1) misuse of budget funds; 2) disinclination to take responsibility and disappointment in the successful implementation of the decentralization reform; 3) lack of support from the general population due to a wrong understanding of the decentralization process and a fear to lost a job; 4) possible resistance from the district administration; 5) inconsistency about the distribution of functions and powers between local authorities and district councils; 6) shortage of educated staff to execute new responsibilities which may lead to ineffective use of financial resources.

It is necessary to introduce effective professional development programs for employees of local self-government, provide them with the necessary advice from the executive authorities and ensure effective control of the objective use of funds to identified certain risks. Today meetings are regularly held with the local population and initiative groups in order to clarify emerging questions, determine strategic goals and tactical problems. 
As a result, the future Pobuzka amalgamated territorial community matches the basic principles of voluntary unification that laid down in the legislation [5]: the continuity of the territory, the ubiquity of local self-government, voluntary association, economic efficiency and the corresponding quality of service. All certain taxes and funds for the provision of administrative service. All of the taxes and administrative fees will go to the budget of a perspective community (it's a significant plus for the unification). But, at the same time, for the present Golovanivskiy district the loss of revenues to its budget from the Pobuzky FerroNickel Combine (which falls within the boundaries of the Pobuzka ATC) will be negative.

\section{References:}

1. Monitoryngh procesu decentralizaciji vlady ta reformuvannja miscevogho samovrjaduvannja. Pidghotovlenyj Ministerstvom reghionaljnogho rozvytku, budivnyctva ta zhytlovo-komunaljnogho ghospodarstva Ukrajiny (2019) [Monitoring of the process of power decentralisation and local governance reform. Prepared by The Ministry for Regional Development, Construction and Public Housing and Utilities of Ukraine] Electronic resources. Retrieved from: https://storage.decentralization.gov.ua/uploads/library/file/470/10.09.2019.pdf (in Ukrainian)

2. Serjoghin S. M., Sharov Ju. P., Borodin Je. I., Ghoncharuk N. T. (2016). Upravlinnja strateghichnym rozvytkom ob'jednanykh terytorialjnykh ghromad: innovacijni pidkhody ta instrumenty [Strategic development management of amalgamation territorial communities: innovative approaches and tools] Dnipro:DRIDU NADU (in Ukrainian)

3. Materialy bjudzhetnykh rozrakhunkiv Pobuzjkoji ghromady za danymy Kirovoghradsjkogho reghionaljnogho viddilennja Asociaciji mist Ukrajiny (2018). [Materials of budget calculations of the Pobuzh community according to the Kirovograd regional branch of the Association of Ukrainian cities]. Retrieved from http://2.auc.org.ua/showmaps (in Ukrainian)

4. Decentralizacija Ukrajiny. Oficijnyj sajt (2018). [Decentralization of Ukraine] Electronic resources. Retrieved from https://decentralization.gov.ua/news/9917 (in Ukrainian)

5. Dobroviljne ob'jednannja ta pryjednannja terytorialjnykh ghromad. Metodychni rekomendaciji ta zrazky dokumentiv (2018). [Voluntary association and union of territorial communities. Guidelines and sample documents]. Retrieved from https://storage.decentralization.gov.ua/ uploads/library/file/167/05.07.pdf (in Ukrainian) 